\title{
Pictures And Words: Celebrating Plurality Through Collaborative Storytelling With Traditional Artists Of Rajasthan, India
}

\author{
Nina SABNANI \\ Industrial Design Centre, Bombay \\ nina.sabnani@gmail.com
}

\begin{abstract}
In Rajasthan, the western region of India, we find a folk tradition of storytelling that is unique for its verbal and visual quality that celebrates plurality. The Kaavad is a painted wooden shrine, used by the itinerant storyteller to recite stories and genealogies for his hereditary patrons. The multi-paneled box is covered with images that are identified by the storyteller as he unfolds the box. He uses the same image to recite multiple narratives and to identify patrons from various villages. Contrary to other practices where the image particularizes the word, here the word or voice particularizes the image. This makes the Kaavad highly inclusive because it allows an image to hold many stories and several persons to be a part of a narrative or shrine.

Inspired and informed by our doctoral research around the Kaavad phenomenon, several media artefacts were created exploring the implicit relationship between words and images. We collaborated with the Kaavad makers and the storytellers to make animated films and illustrated books. In the illustrated book 'Home', we explored the idea of using images as 'prompts' for children to construct their own multiple narratives and to express their worldview around the themes of home and identity. The animated film Baat Wahi Hai (It's the same story) made with traditional artists and storytellers suggests that there are mulitple ways in which ideas may be shared.

In this paper we present our experiments with collaborative storytelling with traditional artists to create an awareness of cultural diversity and to celebrate plurality through words and images.
\end{abstract}

Keywords: Plurality, Cultural diversity, Collaboration, Kaavad 


\section{Introduction}

Pictures and words are both plural in nature; contextually they acquire multiple meanings and are subject to numerous interpretations. They stem from and speak to our senses of seeing and hearing and therefore it is argued that, 'the sensory perception of these categories is not “equal” in all parts' (Varga, 1989, p 32). However, they have long been seen together in children's illustrations, illuminated manuscripts and several other media artifacts such as oral storytelling using painted scrolls and shrines (Mair, 1988; Singh, 1995; Jain, 1998); and readers have negotiated these spaces unconsciously. It has often been said, 'A Picture is worth a thousand words', nonetheless, we need the words to say and communicate this thought. A picture is not simply an image to be read; it invokes memory, imagination and will be interpreted differently by each viewer or reader (Mitchell, 1984). When spoken, words become auditory sounds, and they enter into a dialogue with the image and rather than explaining the image they animate them. How do readers make meaning when they receive pictures and words together is a vast and important area for research but in the context of this paper we are limiting ourselves to understanding the relations between spoken words and images found in the storytelling tradition of Rajasthan, India, and our subsequent experiments creating media artifacts in collaboration with the traditional artists and storytellers in an effort to conserve this intangible heritage. Our theoretical framework has been ethnographic and we used structural and textual analysis lens to interpret our data.

\section{The Kaavad Storytelling Tradition and its Context}

The Kaavad is a painted wooden shrine, used by the itinerant storyteller (Kaavadiya) to recite stories and genealogies for his hereditary patrons. The multi-paneled box is covered with images that are identified by the storyteller as he unfolds the box. He uses the same image to recite multiple narratives and to identify patrons from various villages. Contrary to other 
practices where the image particularizes the word, here the word or voice particularizes the image. This makes the Kaavad highly inclusive because it allows an image to hold many stories and several persons to be a part of a narrative or shrine.

The storyteller brings the Kaavad to his patron's home once a year, which is at the end of the harvest season in winter and performs a recitation. The story themes range from dealing with hardships, making sacrifices, encountering good and evil and making donations. The storyteller begins the recitation by brushing the Kaavad with a peacock feather (considered sacred) to ward off evil, as well as to draw the attention of his listeners by pointing at the images as he gradually turns the panels, embarking on his journey of telling. He alludes to the stories with the bare minimum and does not recite any story fully because it is assumed the patron knows the stories. He mentions the name of the protagonists and the key actions performed by them in the story, thereby invoking the patron's memory and imagination. The community considers such a recitation to be equivalent to performing a pilgrimage. The recitation of the genealogies raises the status of the patron because the storyteller endorses their lineage to a saint or a god. Origin myths reinforce the connection between the community members and their ancestors from the epics. This gives the members the opportunity to raise their status beyond that which is constrained by conventional social stratifications. Elevation of status is also acquired by the recounting of generous donations made by the patron and his extended family. Individual identity is thus acknowledged against the backdrop of a community identity, and seemingly considered important as far as it contributes to finding a 'place' in the community. The Kaavad thus serves the function of sustaining a community. It may be noted that the Kaavad community is a marginalized community that lies outside of the classical Hindu caste system and are referred to as OBCs (Other Backward Classes) by the government of India. The Kaavad storytelling is a living but waning tradition which the community has sustained over time. It is approximately 400 -years 
old (Lyons 2007), although its origin myth suggests that it existed from the times of the Hindu epic Ramayana. The invention of the Kaavad is attributed to a mysterious woman saint called Kundanabai who gifted the portable shrine to the storytellers and they in turn have kept it alive with the help of the artists. The Kaavad is one of the lesser-known forms of storytelling from Rajasthan and shares some traits with the wooden puppets (kathputli) and the painted scrolls (phad); both in the manner of its making and performance. Like the painted scroll it is a portable shrine where religious and heroic tales are recited. And like the wooden puppets it is also a source of entertainment. However, the Kaavad defies restrictive labels like 'artifact', 'painting', 'story', or 'performance'. It is at once all of these and more - a work in which painting, recitation of genealogies, narratives and gesture coalesce to create a complete work of art or an experience.

\section{The Kaavad's Structure}

The Kaavad structure is highly symmetrical. There are sets of hinged panels that fold into each other around a central core, which is the sanctum sanctorum or the innermost shrine. There is an outer and inner shrine that is opened and recited for new and old patrons. During a recitation, the painted panels are unfolded to give the sense of journey, of crossing different thresholds, from the outside to the innermost shrine (Figure 1). This movement enables the storyteller to guide the listeners from one story to another through time to the conclusion of a journey to the inner sanctum where the Gods reside. There are sliding panels that conceal images and are only revealed to a privileged few.

The Kaavad images are arranged in a grid format on each panel and each image exists in its own space. Each image is 'monoscenic' (Dehejia, 1990), representing an entire story and is primarily figurative. Some figures are iconographic, typically amongst which are the gods and demons. The actions of characters surrounding them help identify other figures. For example, Kabir is shown with a loom and Raidas chamar (one who works with leather) is working with 
shoes. Patrons are depicted as couples riding animals or in vehicles (vaahans). The image making also incorporates the new alongside the old, to please all ages and to instill economic pride in their patrons, as seen in the characters riding helicopters and cars. Letterforms and numbers are integrated into the emblematic image reminding us of medieval manuscripts (Schapiro, 1996). Letterforms, animals or birds surrounding the figures serve the function of identifying the patron and the donation made by them. The relationship between spoken words and images in the Kaavad is manifold; images validate what the storyteller is reciting while helping the storyteller recall the sequence of the narrative. The storyteller recites the narrative related to the image, however, this image may not be iconic and may not even represent the protagonist of the story.

As a portable territory (Sabnani, in press), the Kaavad connotes a sacred space or conceptual place of a pilgrimage, offering a liminal experience of travel in space and time. The Kaavad object brings together themes of pilgrimage, storytelling, community, identity and design.

\section{Ethnographic Observations and Analysis about the Kaavad phenomenon}

Our fieldwork observations about the community and performances of Kaavad recitations suggest there is a dynamic relationship between image and voice. The image initiates the memory flow and speech of the storyteller. When he begins to recite the stories or events associated with the image the listener-patron begins to imagine the rest. Since the image is emblematic and does not really illustrate the event or story the listener patron has to exercise his imagination to complete the picture and the events in his mind. With this action, the image is now invested with more meaning than when the image is seen for the first time.

The pictorial representation of patrons in the Kaavad is conceptual because there is no likeness or resemblance to the specific patron. All men look the same and the women look like each other and can assume any role (Figure 2). It is the storyteller who identifies the 
patron by pointing at a specific image. So the generic becomes specific and the specific may become generic at another point.

In a transient mode the mind of the patron accepts the truth of the word and makes them believe the meaning which the storyteller assigns to the image. Not only does the storyteller enthrall the patrons into believing it is them who is represented in the Kaavad, he therefore can use the same image to identify multiple patrons in different locations. At one level it serves the storyteller because he need carry only one Kaavad, which is then particularized for each patron simply through narration and not images. At another level, we may also interpret the form as being highly inclusive, because it implies that everyone is same, thus, it allows several persons to become a part of a narrative or shrine, giving him or her a sense of identity. From a Bakhtinian perspective, the images may also be considered as 'polyphonous' texts (Bakhtin, 1985) since they not only represent multiple voices but also allow for various conflicting voices to be heard. In the Kaavad, during the course of a recitation the patrons recognize the storyteller while he identifies them, and in that sense both interact with each other in a 'polyphonous dialogue'.

When the storyteller points at a figure and identifies it as the image of the patron's ancestor, the conjures an experience of being in the presence of those that are absent, of being in the presence of the dead who are now made eternal. Similarly, when the storyteller points at a figure and identifies it as the patron present, that patron, suspending disbelief, 'enters' the Kaavad's liminal space, 'betwixt and between' (Turner 1969, 1979), where he embraces the painted figure as his own without looking for a likeness.

The Kaavad's distinctive characteristics lie in its ability to be inclusive and collaborative, to negotiate place and space, bringing together imagination and reality, and connecting space, time and memory, pictures and words, and a sense of an imagined real. It is these qualities of the Kaavad that have inspired us to create media artefacts in the form of illustrated books and 
animated films that draw upon these characteristics to be conceptually available to larger urban audiences. Our assumption is that they have relevance for society today and because of its flexibility, the Kaavad has the potential to shape shift into multiple forms without losing its essence.

\section{Designing an Experiment to Elicit Tales: Structuring 'Home'}

Our findings from the Kaavad inspired us to create an illustrated book called Home. Home is a children's picture book sans story. The book is inspired by the unique structure of the Kaavad and its characteristics of inclusivity, community building and the potential for multiple narratives. The word-image relationship explores the possibility of bringing the oral together with the written and the visual; where a reader would need a listener.

Our premise is that if pictures with a few words are provided without narratives, they may motivate a child to create their own stories, individually and as a group. They may share the complex components of their lives and build lucid connections to explore and comprehend what they confront and perhaps even find resolutions. We have also assumed that such a book offers a space for free associations that may provide insights into a child's world and possibly create a platform for an interaction between children, their parents and teachers in formal and informal places. We anticipated the book would lead us to learning about the impact of socio-cultural contexts in interpreting images. It is not a book that is to be read alone. It requires a community of listeners and a reader. Narratives bridge images and words; this is more so when there are gaps between images and words. In the Kaavad the storyteller mediates the gaps. In Home gaps encourage children to connect the two through a narrative and in the process communicate their worldview. We believe children will see the potential of several images being linked together in a story.

'Home' shares a fair amount of similarities with the Kaavad but also differs from it in several ways. Like the Kaavad, the book is structurally designed to be a standing book that can be 
opened in several ways, inciting curiosity. Accordion folded flaps flank a central panel where a cut-out window invites the child to look out at the world through a frame and yet know that what is seen through the frame is a only a part of a whole (Figure 3). The window frame makes them aware of choices of what to include and through that extension know that something is left out. It may also be used as a theatrical stage for children to perform with puppets or toys of their choice or convesre with each other.

In the Kaavad the storyteller points an image and narrates a story, similarly, in the book children are invited to choose any image and narrate a story of their own. All panels have painted pictures against a red background with keywords that prompt discussions around home and family from the human and animal world. One set of flaps has images from the animal world and the other has humans. There is no formal sequence but the images are distributed thematically in clusters on indidividual flaps and within the flap each image is separated by grid lines, as found in the Kaavad. Themes include family, homes, gendered identities and animals. The approach is inclusive as the images portray several families and homes that children could identify with. In the Kaavad one image represents multiple patrons; here too, the image could mean different things to different children, inviting them to draw on their own cultural context. Some may identify with the images, others may recall various tales. Images are not simply representations of reality; they are contextual and suggest worldviews. For example, normative illustrations depict a family unit consisting of father, mother and two children and every child may not feel included. Such depictions may alienate those that do not belong to such a family (Sabnani 2010). In the book, like the Kaavad, there is a possibility of identifying with different kinds of family units; from a large joint family or a single parent unit or a gay couple. When a child looks at an image or text s/he may recalls a story from memory or imagine new ones co-opting the listener as a collaborator for new memories. Unlike the Kaavad, Home, as an object needs no rituals to be performed, it is 
secular in nature and invites universal use. It is not performed by a single individual and can be used by multiple children. It has a cutout window that allows for multiple interpretations on how to engage with it. It is nonlinear and allows students and children to access it in multiple ways as well read the images in any order they wish. There is no tacit understanding between the tellers and listeners; it does not assume a shared knowledge between them. However, a teller may seek collaboration from listeners to move the story forward, a challenge that the Kaavad too offers, conceptually.

\section{'Home' in the Field}

We shared the Kaavad box and the book with children and school teachers in creative workshops in schools, and with parents and children at city festivals in Vadodara, Delhi, Srinagar, Chennai and Mumbai. We also benefitted from independent testing by other researchers located in Mumbai and the UK. Children from various socio-economic segments 'played' with the 'book' (Figure 4). It aroused the curiosity of children and adults alike, because the book could stand up by itself. At first children wanted to know what it was. They wanted to open it from all sides and kept turning the flaps without reading anything. The parents thought the book was to teach young children to recognize the figures. Teachers said they could use it to talk about animals and their habitat. We suggested how the book could be used to elicit stories from children and we demonstrated by first telling a story using an image from the book. Then we invited a child to tell a story using the same image. Soon, everyone wanted to tell their own story and held the book in their hand while telling their story. Some told a known story and others made up their own stories. Some children invented a story around one image and others combined several images to construct their narratives.

In Vadodara, children wanted to make their own version of the book and drew images in them on themes of their own choice. One student made an autobiographic story on adoption using 
the flaps to show a childless couple bringing a child from an orphanage and celebrating her birthday at home (Sabnani, 2010).

Kannal Achuthan, an MPhil student, from the Faculty of Education, University of Cambridge, UK, used the book to explore whether "picture books that offer a gap between the text and the reader offer the most scope to promote verbal, visual and narrative literacies" (Achuthan, 2011). Achuthan carried out the test with two boys and two girls of multiple ethnicities, between the ages five to seven years, in their homes. The children responded to the book structure, to the images and recalled memories of events while looking at some images. They also created their own versions of the book. Some of the findings that were interesting and different for us were their response to the book structure itself. The boys called it a rocket book and the girls said it reminded them of a hotel and home. They invented stories and explanations for the people they saw in the images and one of them said the book reminded them of 'Noah's Ark' (Achuthan, 2011).

A weeklong workshop with Early Learners and kindergarten kids at the American Embassy school in Delhi in 2013, led us to expand the repertoire of the Kaavad and Home to create homelike installations with the children and their teachers. The children were from various countries between the ages of five to seven. It was collaboration between several sections in the school and they made the structure with discarded cardboard boxes on which they pasted their paintings of 'homes' and 'friends' they missed or had left behind. They made large cutouts in the 'walls' and used them as theatre windows to perform with their handmade puppets. The response to the book was like most other children we had met so far. They all wanted to 'play' with it. One group sat around it closing the flaps together to make a shower and wanted others to stay away. One child ran around with the book looking out the cutout window, using it as a frame for himself and as way of looking at everyone. At this point all 
the kids used the cutouts in their installation walls to stick their heads through which to speak to each other.

In a more recent investigation carried out independently by Anisha Dalvi (personal communication, March $\left.5^{\text {th }}, 2014\right)$, the book was shared with underprivileged children at 'Asha for Education', an organization that is actively working towards bringing basic education for a 'socio-economic change' (http://www.ashanet.org). The responses to the images from this group were similar in some instances and quite different to the ones from children going to private schools. They were more inclined to label the images and describe the situation in which the figures were found.

A child seeing the image of a man with balloons said "The balloon man has stolen balloons from someone else and is going to sell these balloons for Rs 2." When probed further as to why he felt the man was a thief, he said 'because he is dark'. This response clearly indicates that color bias has been internalized in some way. In another instance, after seeing the image of a person reading a book outside his house, a child said "The Muslim man is studying in the dark as there is no electricity in his house". This he concluded from the green color of the house and the dark background, a color association with Muslims in India and Pakistan.

Another child combined several images from different flaps of the book to create a narrative about a boy who nearly drowns in the river but is rescued by a dolphin, only to be devoured by a tiger and then saved by a seal and taken home to safety by his mother and sister. In this story the child turned the book several times to identify the different characters that were spread on different flaps and connected them into a complex narrative of being attacked and rescued.

We wanted to explore how one image could have multiple interpretations and this led us to ask three children to narrate stories about a single image. They chose an image of two nomadic women walking with a camel carrying all their belongings including a child, elicited 
three stories from three children with a similar theme of the fear of abandonment (Appendix A).

Finally, we also shared the book with the Kaavad storytellers, even though they were not the identified audience for the book; they were the carriers of the tradition that had inspired us and we were curious to know their responses. They were surprised that the Kaavad could also be made on paper and said the structure reminded them of the Kaavad but the art was different and the folds were not in the 'correct' direction. Two of them discussed three images on a flap and said they could tell one of the Kaavad stories using those images. They wanted to link all three images on a flap to construct a story they knew. They identified the image of a man outside the green house as a schoolhouse with a man studying at the entrance and the nomadic family taking their child to the jungle to collect food. This encouraged us to think about an image's flexibility to be molded for different contexts.

\section{Findings from HOME}

The Home experiment answered some of of our assumptions and also surprised us in some ways. That pictures are plural was obvious from the responses, and children narrated different stories using the same image and even linked some images. As anticipated the book did arouse curiosity, children collaborated by prompting, adding and arguing about known stories. They expressed their worldviews and recalled memories. What we did not anticipate was the use of the book as a toy, or being called a rocket or a hotel. We were surprised by the way children invested meaning into the images, especially dark color being associated with a thief and the stories of abadonment. We did not expect them to connect the several images together even though they were so far apart from each other. Responses like these suggest that a book need not be author-controlled and could offer opportunities for reading in different ways. Reading can also become performance based that brings readers and listeners together as a community just as we observed in a Kaavad recitation. The largest difference between 
the Kaavad and Home that stood out was the way the storytellers look at the image in a Kaavad; for them it is iconic of people and gods, which they only need to recognize, and this is something they will see as a collective, whereas in Home the reader or teller has to find their own individual references and invest that meaning into the picture.

\section{Collaborative Narrative: Baat Wahi Hai (It's the Same Story)}

Although the book was inspired by the Kaavad tradition, conceptually, it was created independently of the traditional artists' involvement in its construction. We wanted to honor them and their resilience to sustain the tradition by telling their story of how they came to be storytellers, in the form of an animated film which will be shared at the end of this paper. We made the film in collaboration with the storytellers and the makers of Kaavads. The storytellers narrated the stories and appeared in the film and the makers painted the figures and backgrounds used in the film.

The idea of making the film emerged from a real situation when we accompanied storyteller Kojaram and his brother Pappuram on their annual visits to their patrons to witness the Kaavad recitation in its natural settings. One day when Pappuram began to narrate his version of a story, Kojaram interrupted him and told a different version of the same story. Both differed over causes but nevertheless agreed to the events in the broader perspective of the narrative (Appendix B). The idea of the film came from this incident as it suggested there was room for plurality and space for interpretation. The film uses a combinaton of live action and animation to show two storytellers presenting their versions of the same story, in this case the story of Shravan Kumar. The story of Shravan Kumar is part of fifty four stories we heard and collected from Kojaram over two years of fieldwork in Rajasthan. It is a very popular story about filial piety from the Hindu epic Ramayana. In the mainstream Hindu version the story is about a devout son Shravan, who carries his sightless parents in a Kaavad (two baskets suspended across a pole and carried on the shoulder) on a journey to visit pilgrim places with 
the hope that they would regain their sight. On the way his parents feel thirsty and when he goes to fetch water from a pond, he is accidentally killed by King Dashrath, father of Lord Rama, who mistakes him for a wild animal. Shravan's parents curse King Dashrath that he too will be separated from his son, after which they die. And their curse comes true and Dashrath too is separated from his son Rama and dies of grief.

In the storytellers version the King is related to Shravan via marriage, he is his maternal uncle. One way kinship bonds are created is through an exchange of woman (Levi Strauss) and in these versions by the storytellers such bonds are created through marriage of Shravan's father with Dashrath's sister. This story was chosen because this community of storytellers believe themselves to be the progeny of Shravan Kaavadiya (the one who carries a Kaavad) and by forging these bonds they elevate their status to being related to royalty as well as their implicit claim of being first cousins with Lord Rama. The story of Shravan Kumar explains how the storytellers are related to him, but the Kaavad of Shravan Kumar does not look like the Kaavad carried by the storytellers. So how does their Kaavad come to be a painted shrine? In the film we tried to together fill the gaps by connecting the two stories. The film therefore attempts to explain and connect the origin myths as well as the many ways the same story can be told, and not only how a story reinvents itself but also how an identity is constructed through narratives.

\section{Weaving the Stories together}

In the process of constructing the narrative there were many occasions for debate and discussion about the characters and what the storytellers felt about them. This discussion itself became a part of the film narrative. The title too emerged from a frequent use of the phrase Baat Wahi Hai, meaning it's the same story or its all the same, when one of them argued with the other. 
We brought together the two versions of the Shravan story and Kundana Bai by structuring the narrative as a gentle argument and conversation between two storytellers, an investigator and the mysterious Kundana Bai, which manifests as the voice of the Kaavad box. One narrative is a lesson in filial piety whereas the other is a subversive tale of impossible marriages. What was interesting to discover in this strange weaving of myth and society was that the differences in the stories related to different patrons each storyteller had and the social status the patrons enjoyed in the larger community.

The Kaavad carried by the mythological character Shravan, bears no resemblance to the portable shrine carried by the storytellers. The Kaavad shrine of the storytellers is like a temple with many doors and thresholds. The shrine denotes a sacred space that is brought to the patrons in lieu of a pilgrimage they cannot make. To explain the gap between the appearance of the Kaavad of Shravan and the Kaavad of the storytellers, another narrative is offered by Kojaram, which concerns a woman benefactor of the storytellers. Her name is Kundana Bai. A woman priest from Kashi, she gifted the Kaavad to the storytellers when they were without any occupation. Her devout nature was rewarded by a boon of immortality. Each morning she would be born a small child, in the day she would turn into a young woman and at night she would become an old lady. Then next morning she was born again as a baby and the cycle continued. When we asked the storytellers why was she born afresh everyday they said 'because to be pure one has to be born afresh'. For us, she embodies 'story' itself, because just as she is born afresh everyday, so is a story born afresh with each telling and with each era over time.

\section{Findings from Baat Wahi Hai (It's the Same Story)}

The collaborative space of making a film gave us opportunities to learn about the community and ways of storytelling. The ease with which the mythic and real integrated, revealed the importance of stories in the community's lives. The story is not just a story, it explains their 
existence. The storytellers wanted to use it as a way to speak about themselves to vistors who did not know much about their tradition.

\section{Conclusion}

Reading pictures in multiple ways is one way of celebrating plurality. At the end we are left with more questions than answers. The pictures in the Kaavad do not draw the attention of the viewer to themselves; they serve as portals or doorways to enter a liminal space. The image also serves to validate the narrative but is a point of departure to enter the imaginary space. This is perhaps possible because the pictures are not illustrative and do not attempt to create resemblances to real people. Pictures can be a powerful way to access memory, imagination and narratives, but do they need to have less information in order to facilitate that? What is the role of words in such a space? The 'experience' of the Kaavad and the book Home is multi-sensory, invoking the senses of sound, touch and sight. Is that the reason for an immediate response from children?

Making the film with the artists, them telling their own stories with their art made us reflect on the nature of collaboration and what was being achieved through such an engagement. Does such an engagement qualify to be termed 'collaborative'?

Is there room for a collaborative inclusive approach that brings together the traditional practitioner communities with others, to sustain, conserve and reinterpret our intangible heritage?

Probing further into the nature of word-image relationships may take us closer to our understanding of a seemingly simple, 'natural' response to their being together. 


\section{References}

Achuthan, K. (2011). One world, many windows: Children's responses to a postmodern picturebook. (Unpublished Mphil paper). University of Cambridge. UK.

Asha for Education (n.d.) Retrieved from http://www.ashanet.org/index.php?page=about

Bakhtin, M. M. (2004). The Dialogic Imagination: Four Essays. (C. Emerson \& M. Holquist, Trans.). Austin: University of Texas Press.

Dehejia, V. (1990). On odes of visual narration in early Budhhist art. The art bulletin 72 (3), 374-392.

Jain, J. (1998). Picture showmen. Mumbai: Marg Publications.

Lévi-Strauss, C. (1968) Structural anthropology. (C. Jacobson, \& B. G. Schoepnf, Trans.) Penguin Books.

Lyons, T. (2007). Mewari perspectives: Udaipur, Nathdwara, Basi. In J. Williams. (Ed.) Kingdom of the sun: Indian court and village art from the princely state of Mewar, 35-51. San Francisco: Asian Art Museum.

Mair, V. H. Painting and performance: Chinese picture recitation and its Indian genesis. Honolulu: University of Hawaii Press, 1988.

Mitchell, W.J.T (1984, Spring). What is an image? New Literary Society 15(3), 503-537. The Johns Hopkins University Press.

Nodelman, P. (1988). Words about pictures: The narrative art of children's picture books, The University of Georgia Press.

Sabnani, N. (2012, Autumn). Prompting narratives: The Kaavad phenomenon. IIC Quarterly, 39 (2), 11-19. New Delhi: India International Centre

Sabnani, N. (In press 2014). Kaavad tradition of Rajasthan: A portable pilgrimage. New Delhi: Niyogi Books. 
Schapiro, M. (1996). Words, script and pictures: Semiotics of visual language. NY: George Braziller.

Singh, K. (1995). The pictures of showmen: Structure and function of images in the picture showmen tradition. Chandigarh: Department of Fine Arts, Panjab University.

Turner, V. (1979). Process, performance and pilgrimage. New Delhi: Concept Publishing Company.

Turner, V. (1969). The ritual process: Structure and anti-structure. NY: Aldine De Gruyer.

Varga, K. A. (1989). Criteria for describing word-image relationship. Poetics Today, 10 (1), 31-53. Duke University Press. 


\section{Appendix A}

Stories told by children at 'Asha for Education', Powai, Mumbai, collected by Anisha Dalvi These are three versions of stories involving the same image by three different children. Story 1- This camel lives in Rajasthan and it is very hot in that desert. The camel is walking on the sand. He falls sick and has fever! Suddenly he falls because he is dizzy. Lots of sand comes on top of him and he gets buried in the sand. A sand mountain is built on the camel. Story2- This is a story about a camel that is walking on the sand and a man is sitting on the camel. The man is watching TV. All of a sudden there is a strong wind and the camel loses balance. The man sitting on camel's back falls down and is left behind. The camel goes away leaving the man behind.

Story 3- These two women are taking the camel to some place. The lady's son is sitting on top of the camel. Because he is very naughty and disturbs the ladies while walking they have put him on the camel. Because he is very naughty they will take him to some unknown place and leave him there or dump him in the sand and go away. 


\section{Appendix B}

Two Versions of the Shravan Kumar Story told by two storytellers

\section{Storyteller 1}

Shravan's parents were Dhanishta and Satviksha and were not always blind. Satviksha was King Dashrath's sister and had no children. She and her husband longed for a son and prayed to Lord Vishnu. The wish was granted but they had to pay a price for that. They were told they could only have a son, if they would sacrifice their sight. They accepted the condition and donated their eyes.

When Shravan grew up, he learned about his parent's sacrifice and went to Lord Vishnu to beg for their sight to be restored. He was asked to take his parents on a pilgrimage to various spots and cleanse them with the holy waters. One day when they were near the kingdom of King Dashrath, his mother asked Shravan to fetch them water to drink. On the other side King Dashrath heard something and thought it was an animal. He shot his arrow that had fire in it (Agnibaan) in that direction. When Dashrath heard Shravan cry out in pain, he realized he had killed his nephew, Shravan. He apologized and explained that it was an accident. The parents cursed him that he too would be separated from his son.

Storyteller 2

Shravan's parents were not always blind. Shravan's father Dhanishta had renounced all pleasures. He went to Lord Vishnu, seeking his advice to find a quiet place where he could meditate. He was told to go where Ram lived. He entered a cave and as he kept going, he began to feel lighter and better. He kept walking, till he felt very calm in one place and he finally settled there. This was the place just below Shri Ram's house. Ram's house was above and Dhanishta sat underground. As it happened to be a household, someone urinated on the ground above and it trickled down and touched the rishi. The rishi was defiled. As a result 
a vine of desire grew from his navel and emerged above the ground. The lady of the house saw the vine and began to water it. It grew. Someone else tied it to a branch and it climbed. And finally it came to the floor of Dashrath's sister Satviksha who was a young unmarried woman. A flower grew from the vine and gave off a heady perfume. She took the flower and rubbed it in her hands. With that action she became pregnant. When the household noticed her condition they sent Sita to inquire about the man in her life. The young woman said she has only seen her father, the sun and the moon. And yes, after rubbing the flower from the vine she had noticed changes in her body. Sita divined the rishi with her powers and told the family where he could be found. They followed the vine underground and discovered the meditating Dhanishta. The rishi was asked to either marry the lady or die. He married the lady on a condition that he would never see her. So he took out his eyes and donated them. The young lady also did the same. She too did not wish to see him. And so Shravan was born of an immaculate conception. And the Kaavadiya Bhats are the progeny of Shravan Kumar. Shravan grew up looking after his parents. He cooked and cleaned for them. A king from a neighboring country wanted his daughter Revati to be married to Shravan. Revati liked Shravan but she did not like his parents, because they were blind and she feared she would be expected to do everything for them. She decided she would kill them by starving them. She got a pot made with a division inside which could not be seen from the outside. On one side she cooked Rab (maize water) and the other side Rabdi (sweetened milk). She fed the parents Rab and her husband Rabdi. Years went by. One day, Shravan was bathing so he gave his share of food to his father with the intention of having his lunch later. When the father ate the Rabdi he asked Shravan if there was a festival being celebrated because he had not eaten Rabdi in a long time. When Shravan asked his wife why his parents never got Rabdi to eat, she showed him the pot from the outside to prove that they have been treated equally. When the parents denied ever having eaten it, she called them senile. Shravan dreamt about the pot 
at night and in the morning went to examine it. He got furious and threw the pot down. It broke and her deceit was revealed.

When he discovered that his wife Revati was being unfair to his parents and ill-treating them, he sent her away and begged for penance. As a part of his penance, he was asked to take his parents on a pilgrimage to various spots and cleanse them with the holy waters. One day when they were near the kingdom of King Dashrath his mother asked Shravan to fetch them water to drink. She cautioned him to make some noise prior to dipping the gourd into the water. Shravan forgot to make the sound. On the other side King Dashrath heard something and thought it was an animal. He shot his arrow that had fire in it (Agnibaan) in that direction. When Dashrath heard Shravan cry out in pain, he realized he had killed his nephew, Shravan. He apologized and explained that it was an accident. Shravan requested him to give the water to his thirsty parents and died without cursing him. When Shravan's mother heard of her son's death she cursed King Dashrath to die of the same arrow that he had used to kill their son. After cursing Dashrath both parents died. 


\section{Figures}

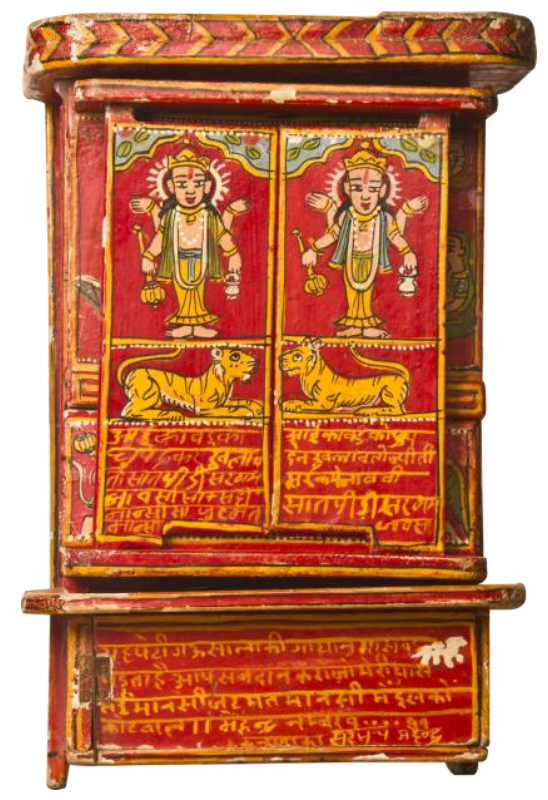

Figure 1. A Closed Kaavad.

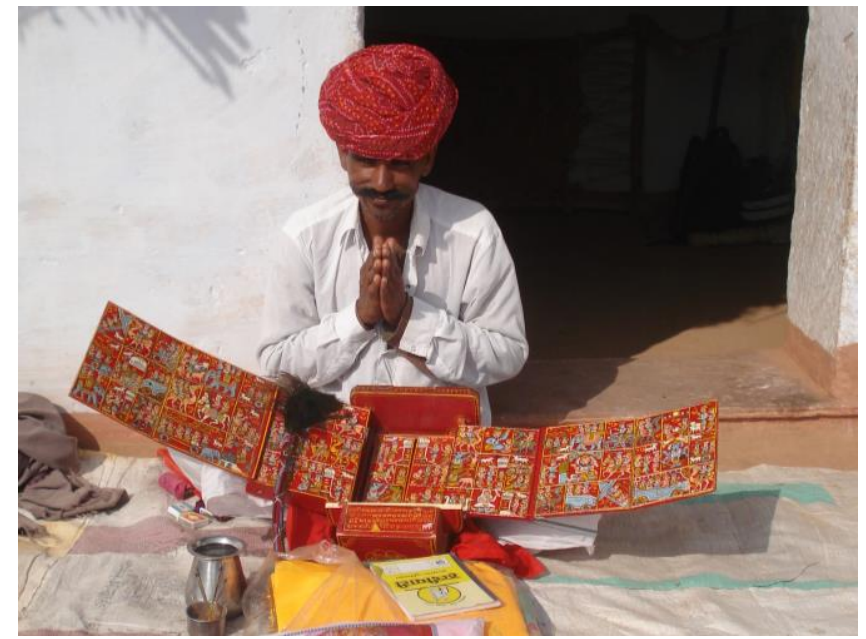

Figure 2. Pappuram with an open Kaavad. 

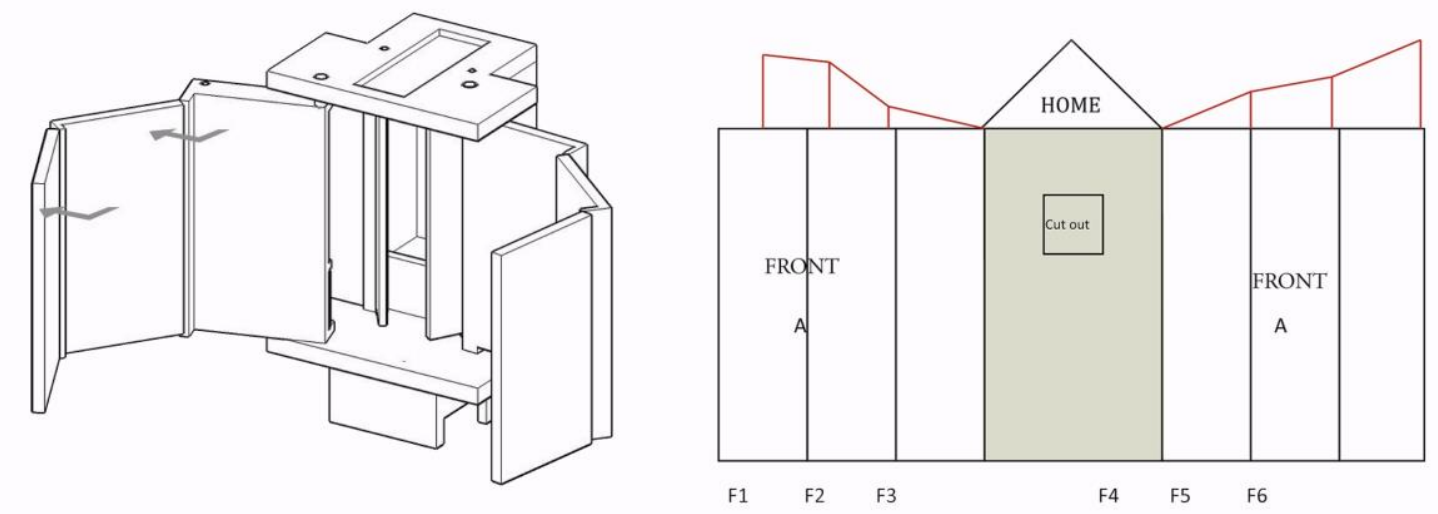

Figure 3. Kaavad structure (left), Home book structure (right).

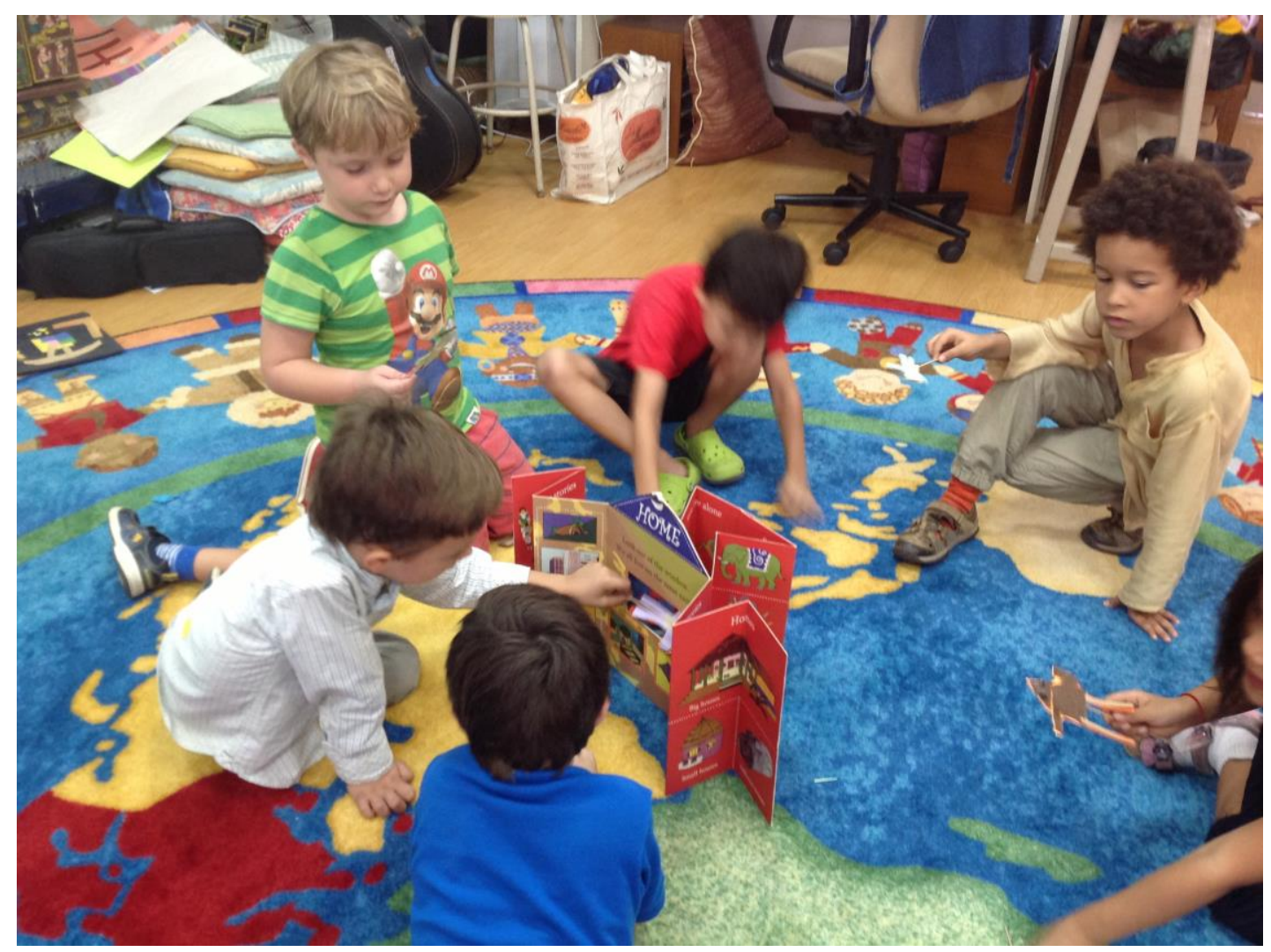

Figure 4. Children playing with Home book. 